\title{
Pengaruh Ragam Sumber Silika Terhadap Pertumbuhan dan Ketahanan Tanaman Padi Terinfeksi Rhizoctonia solani
}

\author{
Juvri Bahtiar ${ }^{1}$, Kharisun $^{2}$, dan Woro Sri Suharti ${ }^{3^{*}}$ \\ 1,2,3 Fakultas Pertanian, Universitas Jenderal Soedirman, \\ Jl. Dr. Suparno 73, Purwokerto \\ 1 Email: woro.suharti@unsoed.ac.id \\ *Penulis korespondensi: woro.suharti@unsoed.ac.id
}

Submit: 26-1-2021

Revisi: 11-5-2021

Diterima: 3-6-2021

\begin{abstract}
Silica has ability to induce the plant resistance against pathogen infections. The research was aimed to determine the effect of various sources of silica in increasing the growth and resistance of rice plants infected by $R$. Solani. The silica sources were consisted of control (without silica source), rice husk ash, rice straw ash, silica sand, and hydrophilic silica $\left(\mathrm{SiO}_{2}\right)$. The observed variables were growth component (plant height, number of leaves, number of tillers, root length, root fresh weight), pathosystem component (incubation period, disease intensity, infection rate, $A \cup D P C$ ), also biochemical and structural component (saponin content, tannin content, total phenol content, epidermal thickness, and stomata density). The result showed that silica application from several ingredients was not able to increase the plant growth, but it was able to support the development of root and leaf. Meanwhile, silica application from several materials was able to increase the resistance of rice plants to against the pathogen $\mathrm{R}$. solani, although it was unable to suppress the incubation period. Rice straw ash was able to increase various kinds of growth variables such as number of leaves, root length, root fresh weight and was able to increase the phenolic compound content and thickness of the epidermis of rice leaves, but had not been able to suppress the pathogen R. solani. $\mathrm{SiO}_{2}$ is able to suppress the development of sheath blight, which is able to reduce the incubation period of up to 5.5 days, a low infection rate of 0.0418 / day, and a relatively low disease intensity of $9.26 \%$.
\end{abstract}

Keywords: Growth, Resistance, Rhizoctonia solani, Rice plant, Silica

\begin{abstract}
ABSTRAK
Silika diketahui dapat menginduksi ketahanan tanaman terhadap adanya infeksi patogen. Penelitian yang dilakukan memiliki tujuan untuk mengetahui pengaruh berbagai sumber silika dalam meningkatkan pertumbuhan dan ketahanan tanaman padi terhadap $R$. Solani. Sumber silika terdiri atas kontrol (tanpa sumber silika), abu sekam padi, abu jerami padi, pasir silika, dan silika hidrofilik $\left(\mathrm{SiO}_{2}\right)$. Variabel yang diamati terdiri atas komponen pertumbuhan (tinggi tanaman, jumlah daun, jumlah anakan, panjang akar, bobot segar akar), komponen patosistem (masa inkubasi, intensitas penyakit, laju infeksi, AUDPC), serta komponen biokimiawi dan struktural (kandungan saponin, kandungan tannin, kandungan fenol total, tebal epidermis, kerapatan stomata). Hasil penelitian menunjukkan pemberian silika dari beberapa bahan dengan dosis $961,8 \mathrm{Kg} / \mathrm{ha}$ belum mampu meningkatkan pertumbuhan tanaman, namun mampu mendukung perkembangan akar dan daun. Sementara itu, pemberian silika dari beberapa bahan mampu meningkatkan ketahanan tanaman padi terhadap patogen $R$. solani, meskipun demikian silika tidak mampu menekan masa inkubasi. Abu jerami padi mampu meningkatkan berbagai macam variabel pertumbuhan seperti jumlah daun, panjang akar, bobot segar akar serta mampu meningkatkan kandungan senyawa fenolik dan ketebalan epidermis daun padi, namun belum mampu menekan patogen $R$. solani. $\mathrm{SiO}_{2}$ mampu menekan
\end{abstract}


perkembangan penyakit hawar pelepah, yaitu mampu menekan masa inkubasi hingga 5,5 hari, laju infeksi yang rendah sebesar 0,0418/hari, dan intensitas penyakit yang tergolong rendah yaitu $9,26 \%$.

Kata kunci: Ketahanan, Padi, Pertumbuhan, Rhizoctonia solani, Silika

\section{Pendahuluan}

Rhizoctonia solani merupakan patogen penyebab hawar daun pelepah yang dapat menyebabkan kehilangan hasil. Berbagai upaya pengendalian telah dilakukan untuk mengendalikan patogen, diantaranya adalah dengan pengunaan agensia hayati, pengendalian secara kultur teknis, fisik, dan varietas tahan. Meskipun demikian, pengendalian tersebut memiliki beberapa kekurangan, sehingga kurang optimal untuk diterapkan (Sumartini, 2012; Hanudin \& Marwoto, 2012). Salah satu pengendalian yang dapat dilakukan adalah dengan pemberian Silika. Silika yang diberikan pada tanaman secara langsung dapat melapisi kutikula tanaman sehingga menghambat proses penetrasi patogen ke jaringan tanaman inang (Vasanthi et al., 2014). Silika juga mampu meningkatkan pertumbuhan tanaman dan menginduksi ketahanan tanaman terhadap infeksi patogen (Sakr, 2016; Wang et al., 2017).

Mekanisme silika sebagai penginduksi ketahanan tanaman terhadap patogen terjadi melalui terbentuknya senyawa komplek dengan silika organik yang berfungsi untuk meningkatkan ketahanan tanaman terhadap aktivitas enzim pengurai yang dihasilkan patogen (Vasanthi et al., 2014). Menurut Fauteux et al., (2005), silika dapat meningkatkan ekspresi mekanisme pertahanan alami dan akumulasi fitoaleksin dalam tanaman. Selain itu, silika dapat berinteraksi dengan sistem sinyal pertahanan tanaman yang memicu munculnya induksi ketahanan terhadap patogen.

Sejumlah penelitian melaporkan bahwa pemberian silika dapat menginduksi ketahanan. Penelitian Song et al., (2016) menyebutkan bahwa kandungan silika dalam silikon berperan terhadap peningkatan ketahanan tanaman padi terinfeksi Xanthomonas oryzae pv oryzae. Pada tanaman jagung, pemberian silika dalam bentuk abu sekam dapat menginduksi ketahanan tanaman terhadap penyakit bulai yang disebabkan oleh Peronosclerospora maydis (Budi \& Majid, 2018).

Silika sebagai unsur yang dibutuhkan tanaman memiliki kelimpahan sangat banyak di tanah (Balai Penelitian Tanah, 2010). Meskipun demikian ketersediannya menjadi rendah karena sejumlah faktor seperti suhu, keasaman tanah dan konsentrasi silika dalam tanah. Kahat silika pada tanaman akumulator seperti padi akan menurunkan keefektifan daun dalam proses fotosintesis, penguapan air tanaman akan meningkat sehingga tanaman menjadi layu, serta rentan terhadap hama penyakit (Makarim et al., 2007).

Silika dapat diperoleh dari bahan organik seperti abu jerami padi dan abu sekam padi, sedangkan silika anorganik dapat diperoleh dari berbagai jenis batuan alam. 
Berdasarkan hal tersebut perlu dilakukannya penelitian mengenai berbagai sumber silika untuk dapat memberikan informasi terkait sumber silika terbaik dalam meningkatkan pertumbuhan dan ketahanan tanaman padi yang terinfeksi $R$. solani.

\section{Metode Penelitian}

Metode yang digunakan adalah Rancangan Acak Kelompok (RAK). Terdapat 5 jenis perlakuan aplikasi sumber silika dengan ulangan sebanyak 6 kali, sehingga diperoleh 30 unit percobaan. Adapun sumber silika yang digunakan terdiri atas kontrol (tanpa sumber silika), abu sekam padi, abu jerami padi, pasir silika, dan $\mathrm{SiO}_{2}$ (hydrophilic silica).

Kandungan $\mathrm{SiO}_{2}$ pada 4 sumber silika telah dianalisis terlebih dahulu di Laboratorium Kimia Fisika Fakultas MIPA Unsoed sehingga diketahui bahwa abu sekam padi, abu jerami padi, pasir silika dan hydrophilic silica memiliki kandungan $\mathrm{SiO}_{2}$ berturutturut sebesar 79,85\%, 84,83\%, 81,38\%, dan 99,80\%. Persentase Si dalam $\mathrm{SiO}_{2}$ dihitung dengan membagi berat atom $\mathrm{Si}$ dengan berat molekul $\mathrm{SiO}_{2}$ dikalikan $100 \%$ sehingga diperoleh nilai $46,74 \%$. Selanjutnya kandungan $\mathrm{SiO}_{2}$ pada masing-masing sumber silika dikalikan 46,74\% untuk mengetahui persentase Si. Adapun hasil perhitungan berupa persentase Si pada 4 sumber silika yaitu abu sekam padi, abu jerami padi, pasir silika dan hydrophilic silica secara berturut turut adalah 37,15\%, 39,64\%, 38,04\%, dan $46,4 \%$. Persentase tersebut dijadikan dasar perhitungan dosis untuk masing-masing perlakuan tiap polibag. Dosis Si per ha yang digunakan menurut Prasetyo et al., (2008) yaitu sebanyak $1400 \mathrm{~kg} /$ ha dengan persentase kandungan $\mathrm{SiO} 2$ sebesar 68,7\%. Berdasarkan data tersebut maka dosis silika per ha yang digunakan adalah sebesar 449,5 kg Si/ha. Berat tanah 1 ha adalah sebesar $2,4 \times 10^{6} \mathrm{~kg}$ dengan berat jenis tanah sebesar $1,2 \mathrm{~g} / \mathrm{cm}^{3}$. Berat tanah per polibag merupakan berat kering mutlak yang diperoleh dari pembagian berat tanah 1 ha $\left(2,4 \times 10^{6} \mathrm{~kg}\right)$ dibagi jumlah tanaman dalam 1 ha (250.000 tanaman), sehingga dihasilkan berat tanah per polibag sebesar 9,6 kg. Dosis Si tiap polibag diperoleh dari perhitungan pembagian berat tanah tiap polibag dibagi berat tanah/ha dikali dosis Si/ha, sehingga diperoleh dosis Si per polibag sebesar 1,798 g Si. Kebutuhan sumber silika per polibag dihitung berdasarkan persentase Si pada masing-masing ragam silika dengan dosis Si per polibag. Adapun kebutuhan sumber silika untuk perlakuan tiap polibag untuk abu sekam padi, abu jerami padi, pasir silika, dan hydrophilic silica secara berturut-turut adalah 4,84 g, 4,54 g, 4,72 g, dan 3,85g. Silika diberikan saat sebelum pindah tanam pada $15,65 \mathrm{~kg}$ tanah inceptisol di dalam polibag berukuran $50 \times 40 \mathrm{~cm}$ yang berisi 1 tanaman padi varietas IR 64 .

$R$. solani yang diinfeksikan pada tanaman diperoleh dari hasil eksplorasi pada tanaman padi yang bergejala hawar pelepah. Patogen diisolasi pada medium PDA 
sehingga diperoleh biakan murni, diidentifikasi dan dibandingkan dengan pustaka untuk selanjutnya dilakukan uji postulat Koch. Inokulasi $R$. solani dilakukan pada saat umur tanaman padi 30 hari setelah tanam (hst) sesuai metode yang dilakukan oleh Suharti et al., (2016).

Pengambilan sampel destruksi dilakukan pada saat umur tanaman 55 hst. Variabel dan pengukuran meliputi: komponen pertumbuhan (terdiri atas tinggi tanaman, jumlah daun, jumlah anakan, panjang akar, bobot segar akar), komponen patosistem (terdiri atas masa inkubasi, intensitas penyakit, laju infeksi, AUDPC), serta komponen biokimiawi dan struktural (terdiri atas kandungan saponin, kandungan tannin, kandungan fenol total, tebal epidermis, kerapatan stomata). Masa inkubasi diamati sejak inokulasi $R$. solani sampai waktu pertama kali muncul gejala awal yang ditunjukkan dengan adanya bercak berbentuk jorong tidak beraturan berwarna coklat. Bagian tengah bercak berwarna putih pucat. Intensitas penyakit dilakukan sesuai Freedman \& MacKenzie (1991) sebagai berikut:

$$
\mathrm{IP}=\frac{\sum(\mathrm{nxv})}{\mathrm{NxV}} x 100 \%
$$

Keterangan: IP = Intensitas penyakit

$$
\begin{aligned}
& \mathrm{n}=\text { Jumlah sampel pada skala tertentu, } \\
& \mathrm{v}=\text { Skala keparahan penyakit } \\
& \mathrm{N}=\text { Jumlah sampel yang diamati } \\
& \mathrm{V}=\text { Skala keparahan penyakit tertinggi. }
\end{aligned}
$$

Skala keparahan penyakit yang digunakan sesuai IRRI (2014) yang dimodifikasi. Skala kerusakan $0=$ tidak ada infeksi, $1=$ infeksi kurang dari 20\%, 3 = infeksi $31 \%-45 \%, 5=$ infeksi 46\%-65\%, 9 = infeksi lebih dari 65\%. Perhitungan laju infeksi dilakukan menurut sebagai berikut:

\section{Keterangan:}

$$
r=\frac{2,3}{t}\left(\log \frac{\mathrm{Xt}}{1-\mathrm{Xt}}-\log \frac{\mathrm{X} 0}{1-\mathrm{X} 0}\right)
$$

$\mathrm{t}$ = Selang waktu pengamatan

$\mathrm{X} 0=$ Proporsi penyakit pada pengamatan pertama

$\mathrm{Xt}=$ Proporsi penyakit pada pengamatan berikutnya 
AUDPC dihitung berdasarkan rumus laju infeksi yang tercantum dalam Jeger \& ViljanenRollinson (2001) sebagai berikut:

$$
A U D P C=\sum_{i=1}^{n}\left[\frac{Y_{i+1}+Y_{i}}{2}\right]\left[X_{i+1}-X_{i}\right]
$$

Keterangan: AUDPC = area under disease progress curve

$$
\begin{array}{ll}
\mathrm{Yi} & =\text { Intensitas penyakit pada pengamatan ke-i } \\
\mathrm{Xi} & =\text { Waktu (hari) pada pengamatan ke-I } \\
\mathrm{n} & =\text { Total pengamatan }
\end{array}
$$

Uji kandungan saponin dilakukan secara kualitatif menggunakan uji busa menurut Syahadat \& Aziz (2012). Keberadaan busa stabil yang terbentuk selama 10 menit merupakan tanda kandungan saponin. Skala yang digunakan, jika berbusa maka diberi simbol + , berbusa tebal dengan simbol ++ , dan berbusa sangat tebal maka ditandai dengan +++. Uji kandungan tanin dilakukan secara kualitatif sesuai Syahadat \& Aziz (2012) dengan penambahan $\mathrm{FeCl}_{3}$. Kandungan tanin ditandai dengan adanya perubahan warna. Skoring perubahan warna untuk warna menjadi coklat, coklat tua, dan coklat kehitaman secara berturut-turut diberi simbol,+++ , dan +++ . Kandungan total fenol dilakukan menurut Pourmorad et al., (2006) dengan modifikasi, menggunakan FollinCiocalteu reagen dan asam galat sebagai standar. Absorban diukur dengan spektrofotometer. Data yang diperoleh dari hasil pengamatan dan pengukuran dianalisis menggunakan uji $\mathrm{F}$ pada taraf kesalahan $5 \%$. Apabila hasil analisis menunjukkan adanya pengaruh nyata maka dilakukan uji lanjut menggunakan uji DMRT (Duncan's Multiple Range Test) pada taraf kesalahan $5 \%$.

\section{Hasil dan Pembahasan}

\section{Komponen Pertumbuhan Tanaman}

Hasil analisis terhadap tinggi tanaman (Gambar 1) menunjukkan perlakuan abu sekam padi, abu jerami padi, pasir silika, dan $\mathrm{SiO}_{2}$ tidak berbeda nyata dibanding kontrol. Hal tersebut diduga karena silika tidak memberikan pengaruh langsung terhadap pertumbuhan tanaman. Hal tersebut sesuai pendapat Wang et al., (2014). Meskipun demikian, pemberian ragam sumber silika menunjukkan tanaman yang lebih tinggi dibandingkan dengan perlakuan tanpa pemberian sumber silika (kontrol). Menurut Fitriani \& Haryanti (2016), silika menyebabkan perubahan fisiologis dan biokimiawi yang merangsang pertumbuhan dan perkembangan tanaman.

Pada variabel jumlah anakan diketahui bahwa pemberian silika tidak berpengaruh nyata terhadap peningkatan jumlah anakan (Gambar 1). Meskipun demikian, jumlah anakan tertinggi terdapat pada perlakuan abu jerami padi. Kandungan silika pada abu jerami lebih rendah dibandingkan dengan sumber silika lainnya, tetapi mampu meningkatkan 
jumlah anakan dibandingkan dengan perlakuan sumber silika lainnya. Hal ini disebabkan terjadinya peningkatan unsur fosfor $(\mathrm{P})$ dalam tanah pada pemberian abu jerami yang dapat dimanfaatkan untuk perkembangan tanaman padi (Saothongnoi et al., 2014), sedangkan penelitian terdahulu menyebutkan bahwa perlakuan pemberian abu sekam tidak berpengaruh nyata terhadap peningkatan P didalam tanah (Harahap et al., 2020). Selain itu, menurut Rahmawati et al., (2018), dosis abu sekam berpengaruh terhadap ketersediaan Si yang dapat dimanfaatkan oleh tanaman. Semakin besar dosis abu sekam yang diberikan pada tanaman maka ketersediaan Si di dalam tanah semakin tinggi yang selanjutnya berdampak pada meningkatnya serapan Si oleh tanaman.

Hasil analisis terhadap jumlah daun menunjukkan perlakuan abu sekam padi, abu jerami padi, pasir silika, dan $\mathrm{SiO}_{2}$ berbeda nyata dibanding kontrol (Gambar 1). Hal ini menunjukkan bahwa perlakuan aplikasi berbagai sumber silika berpengaruh dalam meningkatkan jumlah daun. Menurut Nugroho (2009), pemberian Si yang cukup dapat menekan Al dan Fe pada tanah. Kedua unsur tersebut mampu menjerap P (Nursyamsi \& Setyorini, 2009). Penekanan terhadap Al dan Fe akan menjadikan P tersedia lebih banyak didalam tanah, yang selanjutnya dapat memengaruhi perkembangan pertumbuhan, antara lain jumlah daun (Liferdi, 2010).

Hasil analisis terhadap panjang akar (Gambar 1) diketahui bahwa perlakuan abu sekam padi, abu jerami padi, dan pasir silika tidak berbeda nyata dibanding kontrol, sedangkan perlakuan $\mathrm{SiO}_{2}$ berbeda nyata dibanding kontrol. Diduga konsentrasi Silika yang tinggi pada $\mathrm{SiO}_{2}$ berpengaruh terhadap peningkatan $\mathrm{P}$ di dalam tanah. Hal ini sesuai dengan penelitian Rahmawati et al. (2018) yang menyebutkan bahwa konsentrasi P yang optimum di dalam tanah akan memberikan pengaruh terhadap panjang akar tanaman. Berbeda dengan panjang akar, konsentrasi silika yang dimiliki oleh semua perlakuan berpengaruh terhadap peningkatan bobot segar akar. Kandungan silika pada perlakuan akan meningkatkan $\mathrm{P}$ tersedia, sehingga kebutuhan tanaman terhadap unsur $\mathrm{P}$ untuk perkembangan akar tanaman dapat terpenuhi. 
1. Tinggi Tanaman $(\mathrm{cm})$

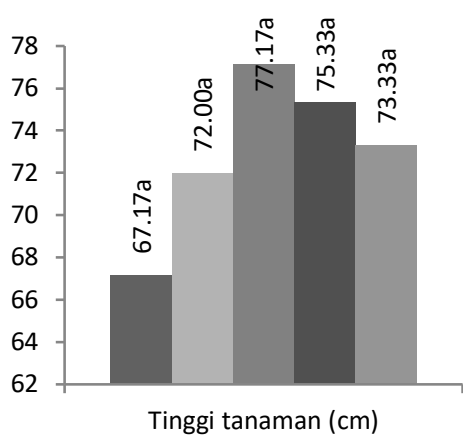

4. Panjang akar $(\mathrm{cm})$

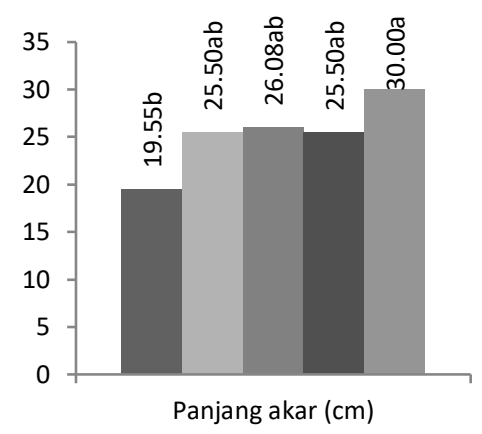

2. Jumlah anakan

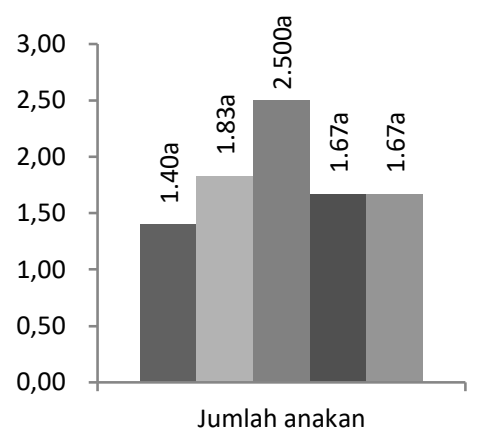

5. Bobot segar akar $(g)$

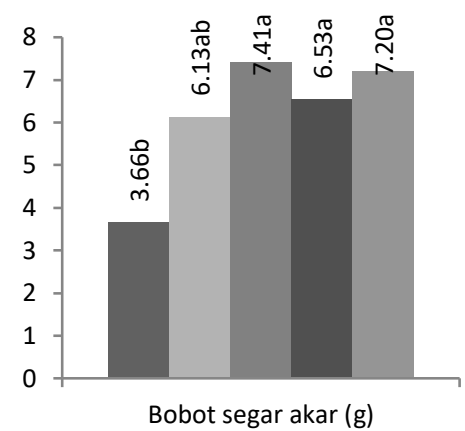

ISSN 2549-7383 (online)

ISSN 2354-7251 (print)

3. Jumlah daun (Helai)

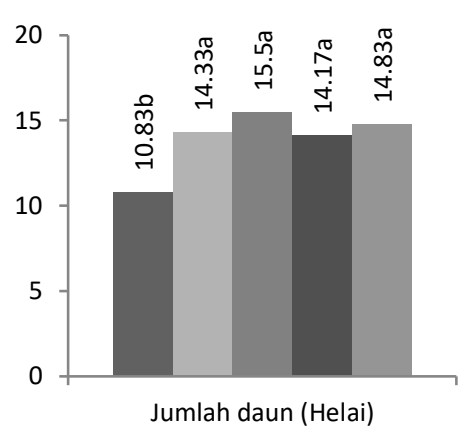

Gambar 1. Histogram pengaruh aplikasi ragam silika terhadap pertumbuhan tanaman. (1) Tinggi tanaman. (2) Jumlah anakan. (3) Jumlah daun. (4) Panjang akar. (5) Bobot segar akar. Angka yang sama pada histogram dengan warna yang sama tidak berbeda nyata pada DMRT $5 \%$.

\section{Komponen Patosistem}

Hasil analisis terhadap masa inkubasi (Gambar 2) menunjukkan adanya perbedaan yang nyata antara perlakuan $\mathrm{SiO}_{2}$ dengan kontrol dan perlakuan lainnya. Peningkatan masa inkubasi pada tanaman yang diberi $\mathrm{SiO}_{2}$ dalam bentuk hydrophilic silica dibandingkan dengan perlakuan lainnya diduga karena kandungan silika yang lebih tinggi pada $\mathrm{SiO}_{2}$ yang mampu memengaruhi lambatnya perkembangan penyakit. Hal ini sesuai dengan penelitian yang dilakukan oleh Seebold et al., (2001) pada tanaman padi terinfeksi Magnaporte grisea. Silika dapat memperlambat masa inkubasi dengan meningkatkan ketahanan tanaman dengan membentuk penghalang sebagai mekanisme fisik yang dapat menghambat penetrasi patogen serta mekanisme biokimiawi dengan menghasilkan enzim dan sinyal yang mengatur ketahanan tanaman (Wang et al., 2017).

Berdasarkan analisis terhadap laju infeksi (Gambar 2), perlakuan abu sekam padi, pasir silika, dan $\mathrm{SiO}_{2}$ berpengaruh nyata terhadap kontrol. Sementara itu, perlakuan abu jerami padi berpengaruh tidak nyata dibandingkan kontrol. Hal ini diduga penambahan unsur silika mampu menekan laju infeksi karena tanaman memiliki dinding sel dan epidermis yang lebih tebal. Hal ini selaras dengan pendapat Dewi et al., (2013) yang 
menyatakan bahwa kuatnya dinding sel disebabkan oleh keberadaan endapan silika. Menurut Hématy et al., (2009), ketebalan dinding sel menjadi penghalang pada sel tanaman untuk meminimalkan penetrasi patogen dan mengurangi penyebaran penyakit.

Hasil analisis terhadap intensitas penyakit pada Gambar 3 menunjukkan adanya perbedaan yang nyata antara perlakuan abu sekam padi, pasir silika, dan $\mathrm{SiO}_{2}$ dibandingkan dengan perlakuan kontrol. Sementara itu perlakuan abu jerami padi tidak berpengaruh nyata dibandingkan dengan kontrol. Perlakuan pasir silika memberikan intensitas penyakit terendah dan tidak berbeda nyata dengan perlakuan $\mathrm{SiO}_{2}$ berdasarkan hasil analisis statistika.

Perlakuan penambahan berbagai sumber silika menunjukkan intensitas penyakit yang lebih rendah dibandingkan kontrol. Hal ini diduga penambahan unsur silika mampu menekan intensitas penyakit karena tanaman memiliki lapisan epidermis yang lebih tebal dan kandungan senyawa fenolik yang lebih tinggi. Menurut Budi \& Majid (2018), silika mampu meningkatkan ketahanan tanaman terhadap serangan hama dan penyakit. Penambahan silika mengakibatkan terjadinya perubahan pada komponen dinding sel. Dinding sel tanaman akan menjadi lebih susah untuk didegradasi oleh enzim patogen.

Analisis terhadap AUDPC (Gambar 3) menunjukkan adanya variasi tingkat ketahanan terhadap penyakit hawar pelepah. Perlakuan $\mathrm{SiO}_{2}$ dan pasir silika menunjukkan tingkat ketahanan yang lebih baik dibanding perlakuan lain. Nilai AUDPC pada setiap perlakuan menunjukkan tingkat ketahanan tanaman. Berdasarkan kriteria tingkat ketahanan menurut Sinaga (2003), maka perlakuan $\mathrm{SiO}_{2}$ termasuk ke dalam kriteria agak tahan, perlakuan pasir silika termasuk kedalam kriteria tahan, sedangkan perlakuan kontrol, abu sekam padi, dan abu jerami padi termasuk kategori rentan. Menurut (Milati \& Nuryanto, 2019), nilai AUDPC yang besar menunjukkan periode tekanan penyakit terhadap tanaman lebih besar.

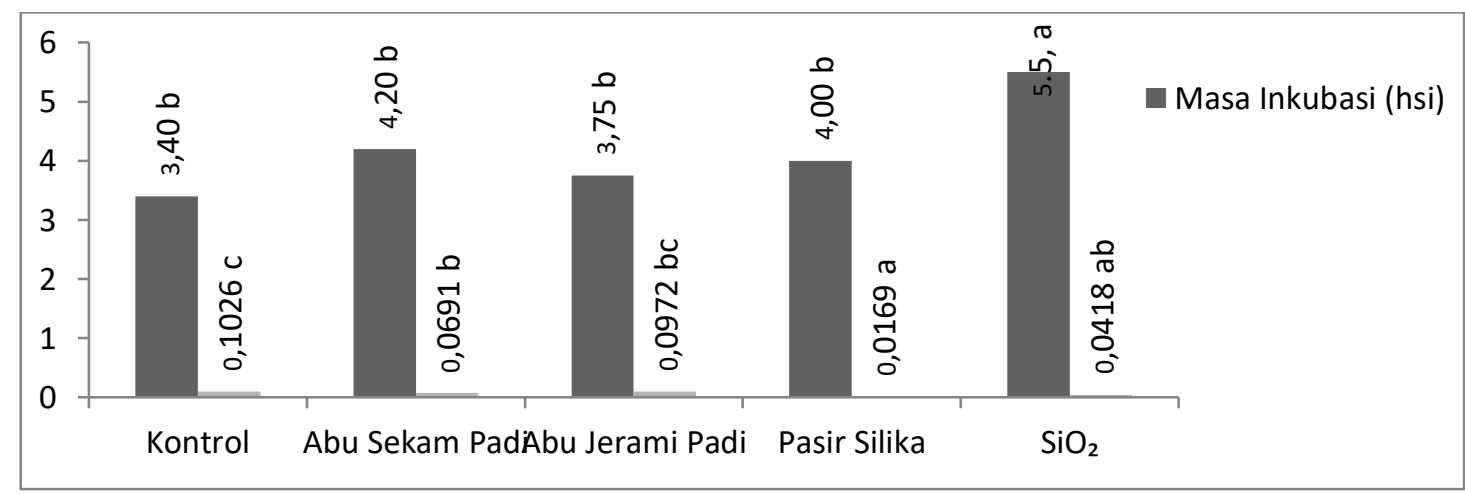

Gambar 2. Histogram pengaruh aplikasi ragam silika terhadap masa inkubasi dan laju infeks. Angka yang sama pada histogram dengan warna yang sama tidak berbeda nyata pada DMRT 5\% 


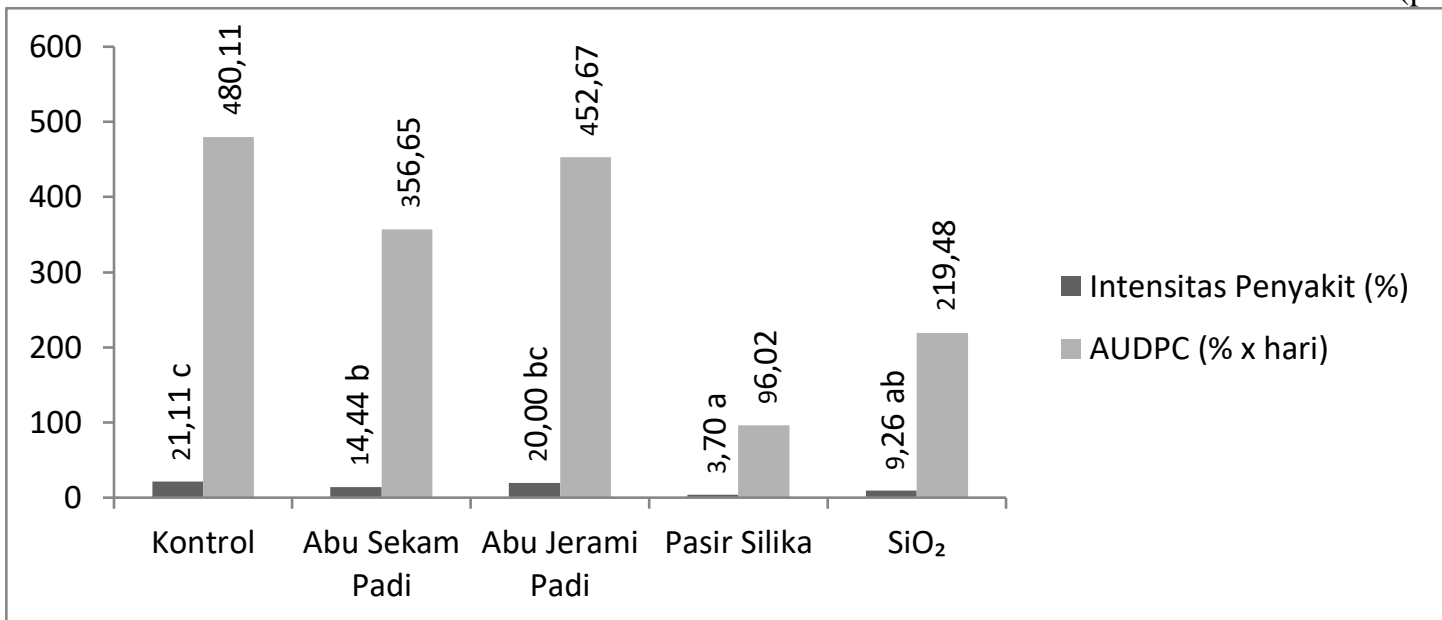

Gambar 3. Histogram pengaruh aplikasi ragam silika terhadap intensitas penyakit dan AUDPC. Angka yang sama pada histogram dengan warna yang sama tidak berbeda nyata pada DMRT 5\%

\section{Komponen Biokimiawi dan Struktural}

Hasil uji saponin menunjukkan perlakuan penambahan abu sekam padi, abu jerami padi, dan $\mathrm{SiO}_{2}$ mampu meningkatkan kandungan saponin dalam tanaman dibandingkan control, sementara itu perlakuan pasir silika tidak mampu meningkatkan kandungan saponin dibandingkan kontrol (Tabel 3). Semua perlakuan positif mengandung saponin ditandai adanya buih stabil yang terbentuk dari permukaan larutan (Gambar 1). Berdasarkan uji tanin yang dilakukan, perlakuan berbagai sumber silika berhasil meningkatkan kandungan senyawa tanin pada tanaman dibanding kontrol (Tabel 3). Saponin dan tanin merupakan senyawa metabolit sekunder yang bersifat antimikroba. Menurut Soesanto et al., (2011), akumulasi kedua senyawa tersebut pada tanaman dapat menjadi penanda terjadinya induksi ketahanan tanaman.

Tabel 3. Pengaruh silika terhadap kandungan saponin dan tanin secara kualitatif

\begin{tabular}{|c|c|c|}
\hline Perlakuan & Saponin & Tanin \\
\hline Kontrol & $+\quad$ (berbusa) & $+\quad$ (coklat) \\
\hline Abu Sekam & ++ (berbusa tebal) & ++ (coklat tua) \\
\hline Abu Jerami & +++ (berbusa sangat tebal) & +++ (coklat kehitaman) \\
\hline Pasir Silika & $+\quad$ (berbusa) & $++\quad$ (coklat tua) \\
\hline $\mathrm{SiO} 2$ & +++ (berbusa sangat tebal) & +++ (coklat kehitaman) \\
\hline
\end{tabular}




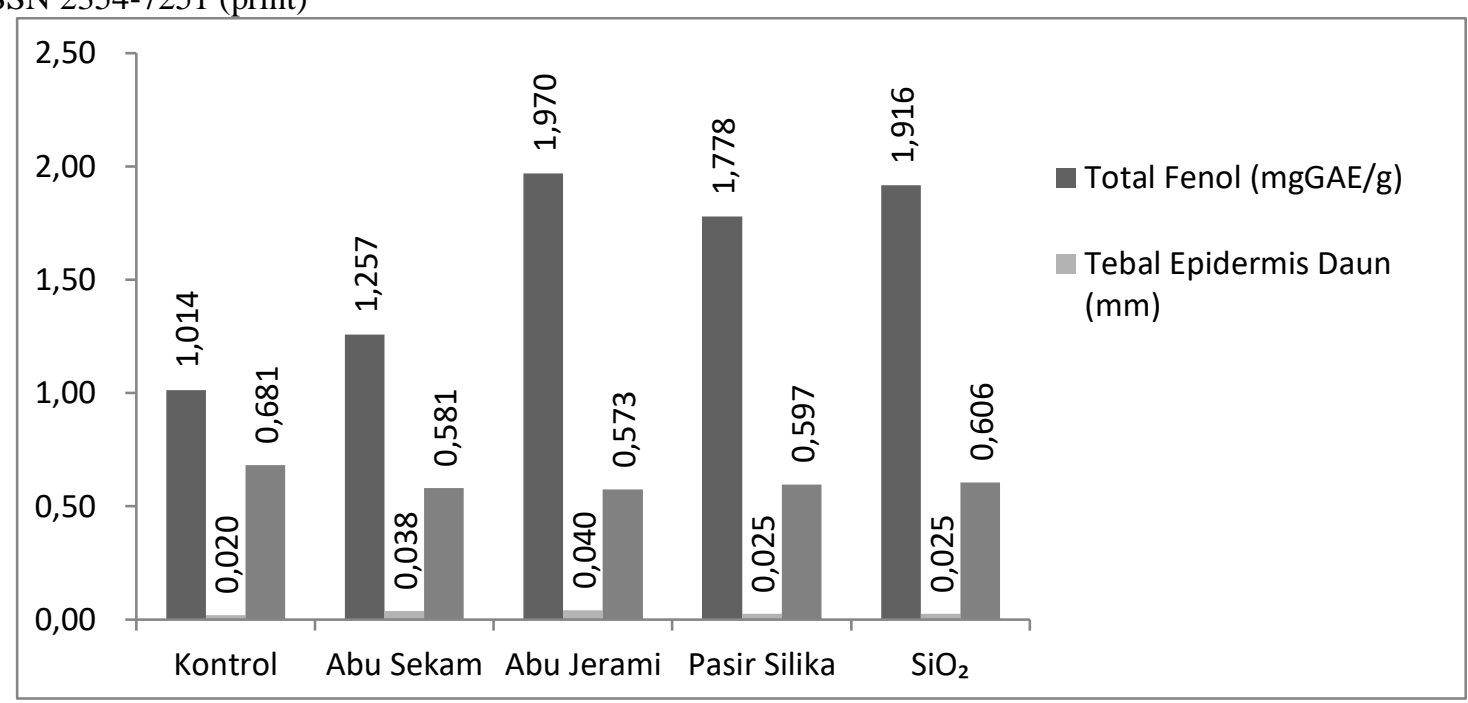

Gambar 4. Histogram pengaruh aplikasi ragam silika terhadap komponen biokimiawi (fenol) dan struktural

Berdasarkan hasil analisis total fenol, kadar total fenol pada perlakuan sumber silika cenderung lebih tinggi dibandingkan kontrol (Gambar 4). Diduga penambahan sumber silika mampu meningkatkan produksi senyawa fenol. Hal ini sesuai dengan pendapat Budi \& Majid (2018) yang menyatakan bahwa silika mampu berperan dalam pembentukan senyawa metabolit sekunder seperti fenol yang berperan dalam ketahanan tanaman. Hasil analisis total fenol menunjukkan kadar fenol yang lebih tinggi pada perlakuan penambahan sumber silika, hal itu selaras dengan intensitas penyakit. Tanaman dengan perlakuan penambahan berbagai sumber silika mampu menekan intensitas penyakit dibandingkan kontrol. Hal ini diduga senyawa fenolik berperan dalam menekan penetrasi patogen. Menurut Lattanzio et al., (2006), senyawa fenol pada tanaman berfungsi sebagai ketahanan tanaman terhadap patogen.

Hasil pengukuran terhadap tebal epidermis daun menunjukkan bahwa perlakuan abu sekam padi, abu jerami padi, pasir silika, dan $\mathrm{SiO}_{2}$ mampu meningkatkan ketebalan epidermis daun padi dibanding kontrol (Gambar 4). Hal ini menunjukkan bahwa perlakuan penambahan berbagai sumber silika berpengaruh dalam meningkatkan ketebalan epidermis tanaman. Hal ini selaras dengan pendapat Putri et al., (2017) yang menyatakan bahwa aplikasi silika akan terakumulasi di kutikula yang selanjutnya dapat menyebabkan peningkatan ketebalan sel epidermis, sehingga patogen sulit untuk melakukan penetrasi ke jaringan tanaman inang. Meskipun demikian, pada perlakuan abu jerami padi nampak bahwa lapisan epidermis yang tebal tidak selaras dengan penekanan laju infeksi. Laju infeksi pada perlakuan abu jerami lebih tinggi dibandingkan dengan perlakuan lainnya diduga disebabkan adanya faktor lingkungan berupa kelembaban yang lebih tinggi. Peningkatan kelembaban terjadi karena pada perlakuan abu jerami padi, jumlah anakan cenderung lebih banyak dibandingkan perlakuan ragam sumber silika lainnya. Menurut 
Nuryanto (2018), jumlah anakan merupakan salah satu faktor yang dapat memengaruhi kelembaban di lingkungan pertanaman yang selanjutnya akan mendukung perkembangan penyakit hawar pelepah.

Penambahan sumber silika tidak berpengaruh terhadap kerapatan stomata (Gambar 4). Hal tersebut selaras dengan penelitian yang dilakukan oleh Amrullah et al., (2014) yang menyatakan bahwa jumlah stomata pada tanaman padi yang diberi silika dan yang tidak diberi silika tidak menunjukkan perbedaan. Pada umumnya perbedaan kerapatan stomata dipengaruhi oleh faktor genetik dan kondisi lingkungan seperti adanya cekaman abiotik kekeringan (Wahyuti et al., 2013; Dama et al., 2020).

\section{Kesimpulan}

Berdasarkan hasil penelitian, dapat disimpulkan bahwa:

1. Pemberian silika dari beberapa bahan mampu meningkatkan ketahanan tanaman padi terhadap patogen $R$. solani, namun tidak mampu menekan masa inkubasi.

2. Pemberian silika dari beberapa bahan dengan dosis $961,8 \mathrm{Kg} / \mathrm{ha}$ belum mampu meningkatkan pertumbuhan tanaman padi, namun mampu mendukung perkembangan akar dan daun.

3. Abu jerami padi mampu meningkatkan berbagai macam variabel pertumbuhan seperti jumlah daun, panjang akar, bobot segar akar serta mampu meningkatkan kandungan senyawa fenolik dan ketebalan epidermis daun padi, namun belum mampu menekan patogen $R$. solani.

4. SiO2 mampu menekan perkembangan penyakit hawar pelepah, yaitu mampu menekan masa inkubasi hingga 5,5 hari, laju infeksi yang rendah sebesar 0,0418, dan intensitas penyakit yang tergolong rendah yaitu $9,26 \%$.

\section{Daftar Pustaka}

Amrullah, Sopandie, D., Sugianta, \& Junaedi, A. (2014). Peningkatan produktivitas tanaman padi (Oryza sativa L.) melalui pemberian nano silika. Jurnal Pangan, 23(1), 17-32. https://doi.org/10.33964/jp.v23i1.46

Balai Penelitian Tanah. (2010). Mengenal Silika sebagai Unsur Hara. Warta Penelitian Dan Pengembangan Pertanian, 32(3), 19-20.

Budi, M. B. S., \& Majid, A. (2018). Potensi Kombinasi TrichodermaSP dan Abu Sekam Padi sebagai Sumber Silika dalam Meningkatkan KetahananTanaman Jagung (Zea mays) terhadap Serangan Penyakit Bulai (Peronosclerospora maydis). Pembangunan Pertanian Dan Peran Pendidikan Tinggi Agribisnis:Peluang Dan Tantangan Di Era Industri 4.0, (November), 732-747. Retrieved from https://jurnal.unej.ac.id/index.php/prosiding/article/view/8985 
ISSN 2354-7251 (print)

Dama, H., Aisyah, S. I., \& Dewi, A. K. (2020). Respon Kerapatan Stomata dan Kandungan Klorofil Padi ( Oryza sativa L .) Mutan terhadap Toleransi Kekeringan. Jurnal Ilmiah Aplikasi Isotop Dan Radiasi, 16(1), 1-6. https://doi.org/10.17146/jair.2020.16.1.5689

Dewi, I. M., Cholil, A., \& Muhibuddin, A. (2013). Hubungan karakteristik jaringan daun dengan tingkat serangan penyakit blas daun (Pyricularia oryzae Cav.) pada beberapa genotipe padi (Oryza sativa L.). Jurnal HPT, 1(2), 10-18.

Fauteux, F., Rémus-Borel, W., Menzies, J. G., \& Bélanger, R. R. (2005). Silicon and plant disease resistance against pathogenic fungi. FEMS Microbiology Letters, 249(1), 16. https://doi.org/10.1016/j.femsle.2005.06.034

Fitriani, H. P., \& Haryanti, S. (2016). Pengaruh Penggunaan Pupuk Nanosilika Terhadap Pertumbuhan Tanaman Tomat (Solanum lycopersicum) var.Bulat. Buletin Anatomi Dan Fisiologi, 24(1), 34-41. https://doi.org/10.14710/baf.v24i1.11691

Freedman, J., \& MacKenzie, D. R. (1991). Disease progress curves, their mathematical description and analysis to formulate predictors for loss equation. In: P.S. Teng (Eds). Journal of Crop Loss Asessment and Pest Management, :37-48.

Hanudin, H., \& Marwoto, B. (2012). Prospek Penggunaan Mikroba Antagonis Sebagai Agens Pengendali Hayati Penyakit Utama Pada Tanaman Hias Dan Sayuran. Jurnal Penelitian Dan Pengembangan Pertanian, 31(1), 30898. https://doi.org/10.21082/jp3.v31n1.2012.p

Harahap, F. S., Walida, H., Oesman, R., Rahmaniah, R., Arman, I., Wicaksono, M., Harahap, D. A., \& Hasibuan, R. (2020). Pengaruh Pemberian Abu Sekam Padi Dan Kompos Jerami Padi Terhadap Sifat Kimia Tanah Ultisol Pada Tanaman Jagung Manis. Jurnal Tanah Dan Sumberdaya Lahan, 7(2), 315-320. https://doi.org/10.21776/ub.jtsl.2020.007.2.16

Hématy, K., Cherk, C., \& Somerville, S. (2009). Host-pathogen warfare at the plant cell wall. Current Opinion in Plant Biology, 12(4), 406-413. https://doi.org/10.1016/j.pbi.2009.06.007

IRRI. (2014). Standard Evaluation System for Rice. IRTP. IRRI. 5ed. Los Banos, Philippines.

Jeger, M. J., \& Viljanen-Rollinson, S. L. H. (2001). The use of the area under the diseaseprogress curve (AUDPC) to assess quantitative disease resistance in crop cultivars. Theoretical and Applied Genetics, 102(1), 32-40. https://doi.org/10.1007/s001220051615

Lattanzio, V., Lattanzio, V. M. T., \& Cardinali, A. (2006). Role of phenolics in the resistance mechanisms of plants against fungal pathogens and insects. In Phytochemistry: Advance in Research (Vol. 661).

Liferdi, L. (2010). Efek Pemberian Fosfor Terhadap Pertumbuhan Dan Status Hara Pada Bibit Manggis. Jurnal Hortikultura, 20(1), 18-26.

Makarim, A. K., Suhartatik, E., \& Kartohardjono, A. (2007). Silikon: Hara Penting pada Sistem Produksi Padi. Iptek Tanaman Pangan, 2(2), 195-204. 
Milati, L. N., \& Nuryanto, B. (2019). Periode Kritis Pertumbuhan Tanaman Padi terhadap Infeksi Penyakit Hawar Pelepah dan Pengaruhnya terhadap Hasil Gabah. Penelitian Pertanian Tanaman Pangan, 3(2), 61-66. https://doi.org/10.21082/jpptp.v3n2.2019.p61-66

Nugroho, B. (2009). Peningkatan Produksi Padi Gogo Dengan Aplikasi Silikat Dan Fosfat Serta Inokulasi Fungi Mikoriza Arbuskular Pada Ultisol. Tesis. Sekolah Pascasarjana Institut Pertanian Bogor. Bogor.

Nursyamsi, D., \& Setyorini, D. (2009). Ketersediaan P Tanah-Tanah Netral dan Alkalin. Jurnal Tanah Dan Iklim, (30), 25-36.

Nuryanto, B. (2018). Pengendalian Penyakit Tanaman Padi Berwawasan Lingkungan Melalui Pengelolaan Komponen Epidemik. Jurnal Penelitian Dan Pengembangan Pertanian, 37(1), 1. https://doi.org/10.21082/jp3.v37n1.2018.p1-8

Pourmorad, F., Hosseinimehr, S. J., \& Shahabimajd, N. (2006). Antioxidant activity, phenol and flavonoid contents of some selected Iranian medicinal plants. African Journal of Biotechnology, 5(11), 1142-1145. https://doi.org/10.1055/s-2007-987042

Prasetyo, T. B., Darfis, I., \& Fitri, R. (2008). Pengaruh Pemberian Abu Sekam Sebagai Sumber Silika (Si) Bagi Pertumbuhan dan Produksi Tanaman Padi (Oriza sativa I.). Jurnal Solum, 5(1), 43-49. https://doi.org/10.25077/js.5.1.43-49.2008

Putri, F. M., Suedy, S. W. A., \& Darmanti, S. (2017). Pengaruh Pupuk Nanosilika Terhadap Jumlah Stomata, Kandungan Klorofil dan Pertumbuhan Padi Hitam (Oryza sativa L . cv . japonica ). Buletin Anatomi Dan Fisiologi, 2(1), 72-79. https://doi.org/10.14710/baf.2.1.2017.72-79

Rahmawati, I. D., Purwani, K. I., \& Muhibuddin, A. (2018). Pengaruh Konsentrasi Pupuk P Terhadap Tinggi dan Panjang Akar Tagetes erecta L. (Marigold) Terinfeksi Mikoriza Yang Ditanam Secara Hidroponik. Jurnal Sains Dan Seni ITS, 7(2), 4-8. https://doi.org/10.12962/j23373520.v7i2.37048

Sakr, N. (2016). Silicon control of bacterial and viral diseases in plants. Journal of Plant Protection Research, 56(4), 331-336. https://doi.org/10.1515/jppr-2016-0052

Saothongnoi, V., Amkha, S., Inubushi, K., \& Smakgahn, K. (2014). Effect of rice straw incorporation on soil properties and rice yield. Thai Journal of Agricultural Science, 47(1), 7-12.

Seebold, K. W., Kucharek, T. A., Datnoff, L. E., Correa-Victoria, F. J., \& Marchetti, M. A. (2001). The influence of silicon on components of resistance to blast in susceptible, partially resistant, and resistant cultivars of rice. Phytopathology, 91(1), 63-69. https://doi.org/10.1094/PHYTO.2001.91.1.63

Sinaga, M. S. (2003). Dasar-Dasar Ilmu Penyakit Tumbuhan. Depok: Penebar Swadaya.

Soesanto, L., Mugiastuti, E., \& Rahayuniati, R. F. (2011). Uji Lapangan Formula Cair Pseudomonas fluorescens P60 terhadap Layu Fusarium pada Tanaman Tomat. Jurnal Perlindungan Tanaman Indonesia, 17(2), 82-90. https://doi.org/10.22146/jpti.9830

Song, A., Xue, G., Cui, P., Fan, F., Liu, H., Yin, C., Sun, W., \& Liang, Y. (2016). The role of silicon in enhancing resistance to bacterial blight of hydroponic- and soil-cultured rice. Scientific Reports, 6, 1-13. https://doi.org/10.1038/srep24640 
Suharti, W. S., Nose, A., \& Zheng, S. H. (2016). Metabolite profiling of sheath blight disease resistance in rice: In the case of positive ion mode analysis by CE/TOF-MS. Plant Production Science, 279-290. https://doi.org/10.1080/1343943X.2016.1140006

Sumartini. (2012). Penyakit tular tanah (Sclerotium rolfsii dan Rhizoctonia solani) pada tanamn kacang-kacangan dan umbi-umbian serta cara pengendaliannya. Jurnal Litbang Pertanian, 31(1), 27-34.

Syahadat, R. M., \& Aziz, S. A. (2012). Pengaruh Komposisi Media dan Fertigasi Pupuk Organik Terhadap Kandungan Bioaktif Daun Tanaman Kemuning (Murraya paniculata (L.) Jack) di Pembibitan. Buletin Penelitian Tanaman Rempah Dan Obat, 23(2), 142-147. https://doi.org/10.21082/bullittro.v23n2.2012.\%25p

Vasanthi, N., Saleena, L. M., \& Raj, S. A. (2014). Silicon in crop production and crop protection -A review. Agricultural Reviews, 35(1), 14. https://doi.org/10.5958/j.09760741.35.1.002

Wahyuti, T. B., Purwoko, B. S., Junaedi, A., \& Abdullah, B. (2013). Hubungan Karakter Daun dengan Hasil Padi Varietas Unggul. Jurnal Agronomi Indonesia, 41(3), 181187. https://doi.org/10.24831/jai.v41i3.8094

Wang, M., Gao, L., Dong, S., Sun, Y., Shen, Q., \& Guo, S. (2017). Role of silicon on plant-pathogen interactions. Frontiers in Plant Science, 8, 1-14. https://doi.org/10.3389/fpls.2017.00701

Wang, W., Yu, Z., Zhang, W., Shao, Q., Zhang, Y., Luo, Y., Jiao, X., \& Xu, J. (2014). Responses of rice yield, irrigation water requirement and water use efficiency to climate change in China: Historical simulation and future projections. Agricultural Water Management, 146, 249-261. https://doi.org/10.1016/j.agwat.2014.08.019 